Jurnal Farmamedika Vol. 1, No. 1 Juni 2016

\title{
POTENSI ENZIM TRANSGLUTAMINASE SEBAGAI GEL PENYEMBUH LUKA STADIUM II PADA AYAM RAS JANTAN
}

\author{
Sitaresmi Yuningtyas ${ }^{1}{ }^{*}$, Abdul Ghoni ${ }^{1}$, Winugroho ${ }^{2}$ \\ ${ }^{1}$ Program Studi S1 Farmasi, Sekolah Tinggi Teknologi Industri dan Farmasi Bogor \\ ${ }^{2}$ Balai Penelitian Ternak, Kementerian Pertanian RI \\ *Korespondensi: sitaresmi_yuningtyas@yahoo.com
}

\begin{abstract}
ABSTRAK
Transglutaminase (E.C. 2.3.2.13) merupakan enzim yang mengkatalisis reaksi perpindahan gugus asil antara kelompok $\gamma$-karboksiamida residu glutamin pada protein, peptida dan berbagai amina primer.Enzim transglutaminase dapat membantu stabilisasi monomer fibrin yang terjadi selama proses pembekuan darah. Tujuan penelitian ini adalah untuk mengetahui aktivitas proses penyembuhan luka stadium II pada ayam ras jantan yang diberikan sediaan gel enzim transglutaminase.Pada penelitian ini dibuat formulasi sediaan gel enzim transglutaminase $1 \%, 3 \%$, $5 \%$, dan $7 \%$.Sediaan gel enzim transglutaminase dilakukan uji organoleptis dan uji homogenitas.Selanjutnya sediaan gel tersebut dioleskan pada ayam ras jantan yang sudah memiliki luka stadium II. Formulasi sediaan gel enzim transglutaminase memiliki tekstur yang homogen, berwarna putih, berbau khas enzim transglutaminase, dan memiliki kisaran $\mathrm{pH}$ 6,2-6,7. Persentase pengurangan panjang luka stadium II pada ayam ras jantan oleh sedian gel enzim transglutaminase $1 \%, 3 \%, 5 \%, 7 \%$, dan Bioplacenton ${ }^{\circledR}$ gel masing-masing sebesar 80,54\%, 99,00\%, 99,67\%, $87,25 \%$, dan $99,33 \%$. Berdasarkan analisis statistik ANOVA, nilai persentase pengurangan panjang luka stadium II dengan perlakuan sediaan gel transglutaminase 5\% lebih tinggi dan berbeda nyata dibandingkan perlakuan dengan gel Bioplacenton ${ }^{\circledR}$ (kontrol positif). Oleh karena itu, sediaan gel enzim transglutaminase 5\% dapat berperan sebagai penyembuh luka stadium II pada ayam ras jantan.
\end{abstract}

Kata kunci: ayam ras jantan, gel, luka stadium II, pengurangan panjang luka, transglutaminase.

\begin{abstract}
The transglutaminase (EC 2.3.2.13) is an enzyme that catalyses an acyl transfer reaction of the $\gamma$ carboxiamide groups glutamine residues in proteins, peptides and various primary amines. Enzyme transglutaminase helps to stabilized the fibrin monomer during the process of blood clotting. This research was to determine the activities of the wound healing process stage II in male broilers given the transglutaminase enzyme sample gels. In this researchgel formulationmadeenzymetransglutaminase $1 \%, \quad 3 \%, \quad 5 \% \quad$ and $7 \%$. Transglutaminaseenzymegelpreparationorganoleptictestandhomogeneity test. Furthermore,thegel formulationapplied to themalebroilersownwoundsstage II. Transglutaminaseenzymegel formulationhad ahomogeneoustexture, white, odorlesstypicalenzymetransglutaminase, andhad apH rangefrom 6.2 to 6.7. The percentagereduction inwoundlength ofstage IIinmalebroilersbyenzymetransglutaminaseperfomedgel1\%, 3\%, 5\%, 7\% and Bioplacenton ${ }^{\circledR}$ gel (positive control) were $80.54 \%, 99.00 \%, 99.67 \%, 87.25 \%$, and $99.33 \%$ respectively. Based on analysis statisticsofANOVA, percentage reduction inwoundlength ofstage Ilby treatment withtransglutaminasepreparationgel5\% higher and significantly differentcompared totreatmentwithBioplacenton $®$ (positive control). Hence, transglutaminaseenzymepreparations5\% gelcanact as awound healerstage Ilinmalebroilers.
\end{abstract}

Keywords: broiler males, gels, reduction length of wound, transglutaminase, wound stage II. 


\section{PENDAHULUAN}

Transglutaminase

(EC

2.3.2.13)

merupakan enzim yang mengkatalisis reaksi perpindahan gugus asil menjadi ikatan kovalen silang diantara protein [1].Enzim ini banyak ditemukan pada liver marmut, ikan, jaringan tumbuhan dan mamalia serta invertebrata. Beberapa industri pangan memanfaatkan enzim transglutaminase, antara lain untuk memperbaiki tekstur keju, mengurangi sineresis (kehilangan air) pada yoghurt, meningkatkan sifat rheologi, enkapsulasi bahan yang berlemak dan larut lemak serta memperbaiki pembentukan gel dan sifat gel [2]. Enzim transglutaminase juga dimanfaatkan pada industri tekstil, yaitu untuk memperbaiki kerusakan yang disebabkan oleh bahan kimia dan protease selama pembuatan wol [3] dan pencucian benang wol [5].

Penggunaan enzim transglutaminase di Indonesia belum begitu banyak. Hal ini dikarenakan sumbernya yang langka, media untuk produksi enzim ini mahal, serta proses pemisahan dan pemurniannya juga rumit. Ando [5] menemukan enzim transglutaminase yang berasal dari Streptoverticillium mobaraenese. Enzim transglutaminase dari mikroba memiliki banyak kelebihan dibandingkan dengan enzim transglutaminase yang diproduksi dari liver marmut, yaitu dapat diproduksi dengan biaya yang lebih rendah dan dalam jumlah besar melalui proses fermentasi sehingga menghasilkan enzim yang lebih murah.Salah satu produk transglutaminase yang telah dipasarkan secara komersial adalah serial Activa $^{\mathrm{TM}}$ Transglutaminase dari Ajinomoto Jepang. Strain yang digunakan adalah Streptoverticillium mobaraense, sehingga transglutaminase yang dihasilkan sering disebut sebagai mikrobial transglutaminase (MTGase).

Penelitian yang menggunakan enzim transglutaminase sebagai suatu sediaan farmasi untuk penyembuhan luka stadium 2 belum ada yang melakukan.Pada penelitian ini, digunakan ayam ras jantan sebagai hewan uji. Alasannya karena secara garis besar kulit ayam sama dengan mamalia, terdiri atas epidermis, dermis dan sub kutan. Selain itu, diperlukan hewan yang memiliki daging yang tebal karena gel enzim transglutaminase akan di uji pada luka stadium II, yaitu hilangnya lapisan kulit pada lapisan epidermis dan bagian atas dari dermis.Luka stadium II (Partial Thickness) adalah hilangnya lapisan kulit pada lapisan epidermis dan bagian atas dari dermis yang ditandai dengan abrasi, blister atau lubang yang dangkal. Pisano et al., [6] menyatakan bahwa enzim transglutaminase dapat membantu stabilisasi monomer fibrin yang terjadi selama proses pembekuan darah. Transglutaminase juga dikenal sebagai Faktor XIIIa di bidang kedokteran, yang berperan pada proses penggumpalan darah.MTG-ase dapat ditemukan pada berbagai organ, jaringan, dan cairan tubuh hewan (darat maupun air) dan tanaman. Enzim ini terlibat pada berbagai fungsi biologis mulai dari penggumpalan darah sampai diferensiasi sel [7]. Berdasarkan hal tersebut, enzim transglutaminase ini diduga dapat berfungsi sebagai obat perekat luka stadium II yang memiliki prospek yang sangat baik untuk dikembangkan menjadi sediaan farmasi. Oleh karena itu, penelitian ini bertujuan untuk menentukan potensi penyembuhan luka stadium II pada ayam ras jantan yang diberikan sediaan gel enzim transglutaminase $1 \%, 3 \%$, 5\% dan $7 \%$. Selain itu, hasil proses penyembuhan luka tersebut akan dibandingkan dengan sediaan Bioplacenton ${ }^{\circledR}$ gel sebagai kontrol positif.

\section{METODE PENELITIAN}

Bahan: ayam ras jantan berumur 3-4 bulan dengan bobot 1,3-1,5 $\mathrm{kg}$, pakan ayam, Bioplacenton $^{\circledR}$ gel,alkohol $70 \%$, Activa ${ }^{\mathrm{TM}}$ Transglutaminase dari Ajinomoto, CMC-Na, nipagin, nipasol, propilenglikol dan akuades.

Alat: timbangan analitik, mortir, stamper, sudip, kertas perkamen, gunting pencukur bulu, penggaris, surgical blade sterile,bisturi no.15, pot salep, sarung tangan, masker, dan pinset.

\section{Metode}

\section{Pembuatan Sediaan Gel Transglutaminase} [8]

Pembuatan gel enzim transglutaminase menggunakan teknik pencampuran.Hal yang pertama dilakukan adalah seluruh bahan yang dibutuhkan ditimbang, disiapkan air panas yang sudah diukur kemudian dimasukkan ke dalam mortir lalu ditaburkan CMC-Na secara merata, ditunggu hingga mengembang. Pada mortir yang berbeda dilarutkan enzim transglutaminase dengan propilenglikol, setelah homogen dimasukkan nipagin dan nipasol lalu digerus lagi hingga homogen. Setelah CMC-Na mengembang, dimasukkan campuran propilen glikol dan enzim transglutaminase dan digerus hingga homogen.Komposisi formula gel enzim transglutaminase dapat dilihat pada Tabel 1. 
Tabel 1. Komposisi sediaam gel transglutaminase

\begin{tabular}{lcccc}
\hline \multicolumn{1}{c}{ Bahan } & Formula 1 & Formula 2 & Formula 3 & Formula 4 \\
\hline Propilenglikol & $1 \%$ & $1 \%$ & $1 \%$ & $1 \%$ \\
CMC-Na & $3 \%$ & $3 \%$ & $3 \%$ & $3 \%$ \\
Nipagin & $0,1 \%$ & $0,1 \%$ & $0,1 \%$ & $0,1 \%$ \\
Nipasol & $0,05 \%$ & $0,05 \%$ & $0,05 \%$ & $0,05 \%$ \\
Enzim Transglutaminase & $1 \%$ & $3 \%$ & $5 \%$ & $7 \%$ \\
Akuades ad & $100 \mathrm{ml}$ & $100 \mathrm{ml}$ & $100 \mathrm{ml}$ & $100 \mathrm{ml}$ \\
\hline
\end{tabular}

Keterangan : Gel dibuat 100 gram untuk masing-masing formulasi (dalam $\%$ b $/ \mathrm{b}$ )

\section{Evaluasi Sediaan Gel Transglutaminase}

Uji Organoleptis: Evaluasi organoleptis menggunakan panca indra mulai dari bau, warna, tekstur sedian, dan konsistensi.

Uji Homogenitas: pengujian homogenitas yaitu dengan cara gel diletakkan pada kaca objek kemudian meratakannya untuk melihat adanya partikel-partikel kecil yang tidak terdispersi sempurna.

Evaluasi pH: Evaluasi pH menggunakan alat $\mathrm{pH}$ meter

\section{Uji Penyembuhan Luka}

Penyiapan hewan coba: Hewan coba yang digunakan pada penelitian ini adalah ayam ras jantan berumur 3 - 4 bulan dengan bobot sekitar 1,3 - 1,5 kg yang diperoleh dari peternakan ayam ras. Sebanyak 24 ekor ayam ras dibagi menjadi 6 kelompok perlakuan, masing - masing kelompok terdiri dari 4 ekor.Ayam ras tersebut dikandangkan secara terpisah dengan jumlah ayam ras per-kandang 4 ekor.Selama penelitian semua kelompok ayam ras diberi pakan ayam ras dan minum. Semua hewan coba tersebut dilakukan adaptasi selama 1 minggu.

Perlukaan pada hewan coba: hewan uji dicukur bulunya di daerah paha sampai licin kemudian dibersihkan dengan alkohol $70 \%$. Selanjutnya dibuat luka berdiameter $3 \mathrm{~cm}$ dan kedalaman $0,5 \mathrm{~cm}$ dengan cara disayat dengan pisau bedah steril (bisturi no. 15). Kelompok perlakuan dibagi menjadi 6 kelompok:

1) Kelompok A : luka diberi dasar gel (kontrol negatif).

2) Kelompok B : luka diberi Bioplacenton ${ }^{\circledR}$ gel (kontrol positif).

3) Kelompok C : luka diberi formula 1 (konsentrasi 1\% enzim transglutaminase).

4) Kelompok D : luka diberi formula 2 (konsentrasi 3\% enzim transglutaminase).

5) Kelompok E : luka diberi formula 3 (konsentrasi 5\% enzim transglutaminase).

6) Kelompok $\mathbf{F}$ : luka diberi formula 4 (konsentrasi 7\% enzim transglutaminase).
Pemberian obat dan gel transglutaminase pada hewan coba. Pemberian obat dan gel transglutaminase dilakukan dengan cara sediaan dioleskan merata sebanyak $\pm 20 \mathrm{mg}$ pada bagian luka secara tipis-tipis setiap 2 kali sehari selama 10 hari.

Pengamatan pada luka. Pengamatan pada luka dilakukan setiap hari selama 10 hari dengan mengamati tanda-tanda kesembuhan dengan cara mengukur panjang luka.

\section{Anali Analisis Data}

Pada penelitian ini data yang diperoleh dari hasil pengukuran panjang luka akan ditabulasikan kemudian dianalisis secara statistik dengan SPSS menggunakan metode ANOVA Rancangan Acak Lengkap dan dilanjutkan dengan uji Duncan.

\section{HASIL DAN PEMBAHASAN Pembuatan Sediaan Gel Transglutaminase}

Gel merupakan sediaan semipadat yang jernih, tembus cahaya dan mengandung zat aktif. Alasan dibuat dalam bentuk sediaan gel adalah untuk memberikan suasana dingin pada saat pemakaian secara topikal, mempunyai daya sebar yang baik dan terlihat lebih elegan karena warnanya yang transparan. Dalam pembuatan gel ini digunakan bahan aktif enzim transglutaminase yang berupa tepung berwarna putih dan berbau khas.Temperatur optimum aktivitas enzim transglutaminase terjadi pada suhu $50^{\circ} \mathrm{C}$, maka dalam pembuatan gel enzim transglutaminase dilakukan pada suhu optimum tersebut.Pada tahap pencampuran enzim transglutaminase dengan basis salep harus dilakukan pada suhu $\pm 50^{\circ} \mathrm{C}$ agar enzim transglutaminase tidak terdenaturasikan dan aktivasnya lebih baik.

Sebagai bahan dasar gel digunakanCarboxy Methyl Celulosum Natricum (CMC-Na) yang merupakan serbuk atau granul, putih sampai krem, higroskopik, mudah terdispersi dalam air membentuk larutan koloidal, tidak larut dalam etanol, dalam eter dan dalam pelarut organik lain. CMC-Na digunakan sebagai bahan dasar untuk 
membentuk gelkarena karakteristiknya yang mudah mengembang dengan prosedur pembuatan yang benar, dapat bercampur dengan bahan aktif dan tampilannya yang jernih merupakan solusi bahan yang cocok digunakan sebagai pembentuk gel.Propilenglikol digunakan sebagai bahan tambahan supaya masa gel lebih lunak dan terlihat transparan.Selain itu, penambahan propilenglikol juga bertujuan untuk mencegah kehilangan air karena propilenglikol bersifat higroskopis.Nipagin dan nipasol berguna sebagai pengawet supaya gel tidak mudah ditumbuhi mikroba.Pengawet ditambahkan karena gel mengandung banyak air sehingga membutuhkan pengawet sebagai antimikroba.

\section{Evaluasi Sediaan Gel Transglutaminase}

Evaluasi sediaan dimaksudkan untuk menguji kesesuaian sediaan yang dibuat dengan kriteria atau persyaratan yang berlaku untuk sediaan gel serta untuk menjaga kestabilan sedíaan.Hasil uji organoleptis dan $\mathrm{pH}$ dapat dilihat dalan Tabel 2.Berdasarkan Tabel 2, uji bau antara dasar gel dengan gel enzim transglutaminase $1 \%, 3 \%, 5 \%$ dan $7 \%$ menunjukkan adanya perbedaan. Dasar gel tidak berbau, sedangkan gel enzim transglutaminase berbau khas enzim transglutaminase.Pada uji warna juga ada perbedaan, yaitu antara dasar gel yang transparan dan gel enzim transglutaminase berwaran putih transparan.Perbedaan warna pada gel enzim transglutaminase dikarenakan enzim transglutaminase berwarna putih. Uji $\mathrm{pH}$ dilakukan karena gel enzim transglutaminase ini untuk penggunaan topikal, maka sediaan harus mempunyai tingkat keasaman atau $\mathrm{pH}$ dalam rentang $\mathrm{pH}$ dari permukaan kulit yaitu 4,5-6,5 [9]. Hal ini dikarenakan sediaan yang terlalu asam akan menyebabkan iritasi pada kulit, sedangkan sediaan yang terlalu basa akan membuat kulit menjadi kering.

Pada uji $\mathrm{pH}$ dengan menggunakan alat $\mathrm{pH}$ meter didapatkan $\mathrm{pH}$ sedíaan gel enzim transglutaminase memiliki kisaran $\mathrm{pH}$ sebesar $6,2-6,7$. Dasar gel mempunyai $\mathrm{pH}$ sebesar 6,2, nilai $\mathrm{pH}$ dasar gel perlu diperhatikan karena $\mathrm{pH}$ optimum aktivitas enzim MTGase terjadi pada pH 6-7, maka perlu digunakan dasar gel yang bersifat netral. CMC-Na dipilih sebagai dasar gel karena bersifat netral, tahan terhadap degradasi enzimatik, viskositasnya stabil, warnanya jernih transparan dan menghasilkan lapisan film yang kuat pada kulit.Formulasi dasar gel dan enzim transglutaminase $1 \%$ mempunyai $\mathrm{pH} 6,2$. Formulasi dasar gel yang ditambahkan enzim transglutaminase 3\%, 5\%, dan $7 \%$ mempunyai $\mathrm{pH}$ masing-masing 6,3 ; 6,5; dan 6,7. Berdasarkan pada data tersebut, penambahan enzim dapat meningkatkan $\mathrm{pH}$ disebabkan oleh komposisi Activa ${ }^{\mathrm{TM}}$ Transglutaminase dari Ajinomoto yang digunakan terdiri atas protein susu, laktosa, dekstrin, sodium tripolifosfat, tetrasodium pirofosfat dan silikon dioksida.

Keempat formula gel yang dibuat, hanya formula ke-4 dengan konsentrasi enzim transglutaminase sebesar 7\% yang melebihi persyaratan. Formula gel dengan konsentrasi enzim transglutaminase $1 \%, 3 \%$ dan 5\% yang memenuhi persyaratan dalam pembuatan gel karena formula tersebut berada pada kisaran 4,5-6,5. Oleh sebab itu, formulasi gel dengan konsentrasi tersebut cocok dan tidak iritatif secara topikal pada kulit.

Gel yang sudah dibuat, lalu dimasukan ke dalam wadah pot plastik dan disimpan selama 7 hari pada suhu kamar, untuk mengetahui kestabilan gel. Hasil pengamatan setelah 7 hari, sediaan gel tidak mengalami perubahan warna, bentuk, bau, dan $\mathrm{pH}$ pada formula 1, 2 dan 3 . Sedangkan untuk formula 4 ada perubahan bentuk gel menjadi agak menggumpal dan terpisah antara dasar gel dengan enzim transglutaminase. Hal ini terjadi karena adanya sineresis yaitu suatu proses yang terjadi akibat adanya kontraksi di dalam massa gel sehingga gel tampak menggumpal dan air mengambang di atas permukaan gel.

Tabel 2. Hasil evaluasi sediaan gel enzim transglutaminase

\begin{tabular}{lccccc}
\hline $\begin{array}{c}\text { Uji } \\
\text { Organolepti } \\
\text { s }\end{array}$ & $\begin{array}{c}\text { Dasar } \\
\text { Gel }\end{array}$ & \multicolumn{4}{c}{ Formula } \\
\cline { 3 - 5 } & & $\begin{array}{c}\mathbf{1} \\
\text { (enzim 1\%) }\end{array}$ & $\begin{array}{c}\mathbf{2} \\
\text { (enzim 3\%) }\end{array}$ & $\begin{array}{c}\mathbf{3} \\
\text { (enzim 5\%) }\end{array}$ & $\begin{array}{c}\mathbf{4} \\
\text { (enzim 7\%) }\end{array}$ \\
\hline Bau & Tidak & Bau khas & Bau khas & Bau khas & Bau khas \\
& Berbau & enzim & enzim & enzim & enzim \\
& & transglutaminas & transglutaminas & transglutaminas & transglutaminas \\
& & e & e & e & e \\
Warna & Transpara & Putih & Putih & Putih & Putih \\
& $n$ & Transparan & Transparan & Transparan & Transparan \\
\hline
\end{tabular}


45 | Antonius Padua Ratu, et.al.( Uji Antioksidan Ekstrak Pigmen ...)

\begin{tabular}{lccccc}
\hline Bentuk & Gel & Gel Homogen & Gel Homogen & Gel Homogen & Gel Homogen \\
pH & 6,2 & 6,2 & 6,3 & 6,5 & 6,7 \\
\hline
\end{tabular}

\section{Uji Penyembuhan Luka}

Berdasarkan Gambar 1, keseluruhan perlakuan pada hewan uji menghasilkan penurunan panjang luka seiring dengan bertambahnya hari. Pada hari ke-10, panjang luka sudah menurun sehingga dapat dijadikan indikator penyembuhan luka.Pengurangan panjang luka dimulai hari ke-1 sampai hari ke10 dari semua perlakuan.Pengurangan signifikan panjang luka terlihat pada hari ke-4 yaitu pada fase proliferasi, sedangkan pada hari ke-1 sampai hari ke-3 merupakan fase inflamasi. Proses inflamasi berlangsung 3-4 hari pada proses penyembuhan luka [10]. Pada penelitian ini, pengamatan makroskopik proses penyembuhan luka pada fase inflamasi untuk kelompok perlakuan pemberian gel enzim transglutaminase $1 \%, 3 \%, 5 \%$ dan $7 \%$ memberikan hasil inflamasi yang tidak terlalu bengkak dibandingkan dengan kelompok kontrol negatif. Berdasarkan penguian statistika dengan ANOVA yang dilanjutkan uji Duncan menunjukkan perbedaan yang signifikan antara panjang luka dan hari perlakuan.Maka dapat disimpulkan bahwa dengan adanya perlakuan luka yang diberikan sediaan gel transglutaminase dapat memberikan perbedaan nyata terhadap pengurangan panjang luka.

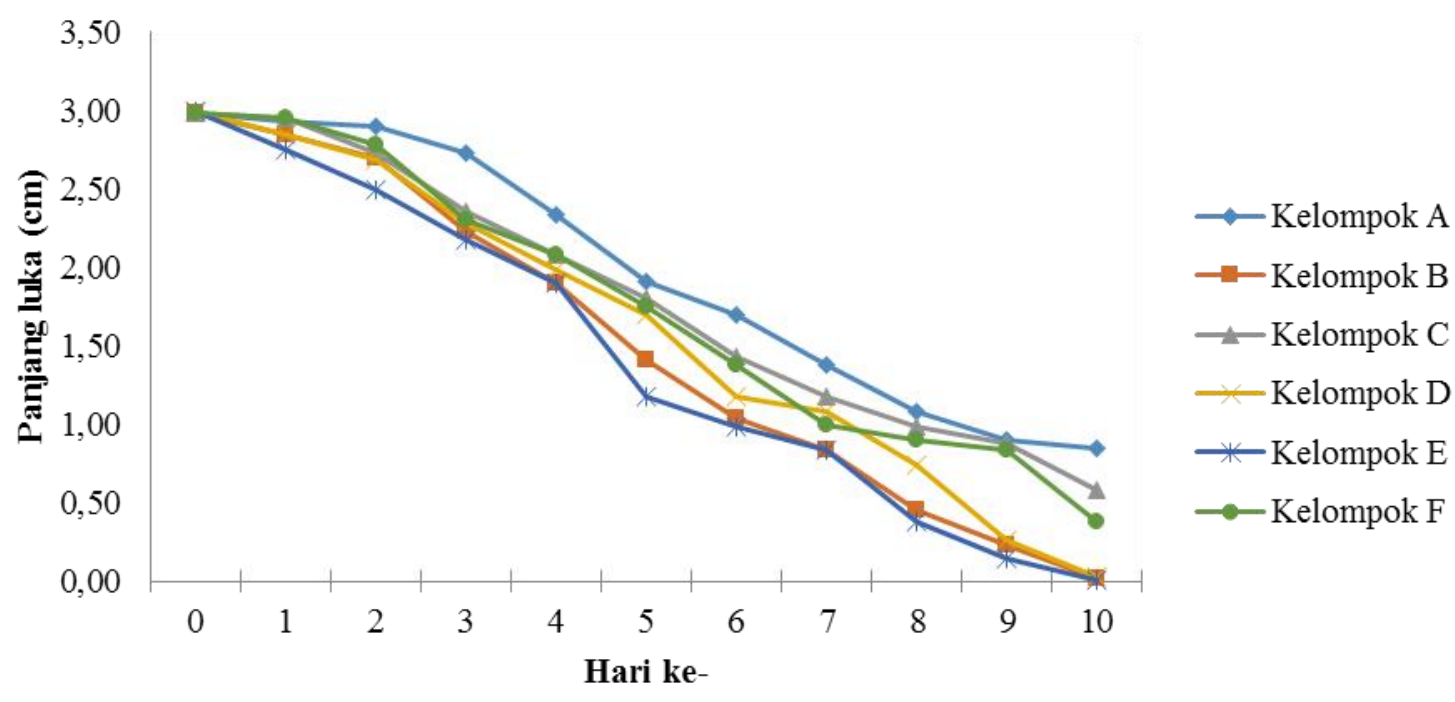

Gambar 1. Grafik perubahan panjang luka ayam ras jantan selama 10 hari 
Berdasarkan Tabel 3, luka stadium II pada ayam yang diberikan olesan sediaan gel enzim transglutaminase $1 \%, 3 \%, 5 \%$ dan $7 \%$ memiliki persentase pengurangan panjang luka masingmasing sebesar $80,54 \%, 99,00 \%, 99,67 \%$ dan $87,25 \%$. Persentase pengurangan panjang luka paling tinggi terdapat pada perlakuan dengan sediaan gel enzim transglutaminase 5\% sedangkan persentase terendah terdapat pada sediaan gel enzim transglutaminase $1 \%$.Hasil analisa statistik terhadap data yang diperoleh menggunakan analisa sidik ragam ANOVA menunjukkan adanya perbedaan yang pengurangan panjang luka antar perlakuan.Hasil uji lanjut Duncan, antara panjang luka yang diberikan sediaan gel enzimtransglutaminase $1 \%$ dan $7 \%$ tidak berbeda nyata.Sedangkan gel enzim transglutaminase $3 \%, 5 \%$, kontrol positif dan kontrol negatif memiliki perbedaan yang nyata.Berdasarkan analisis statistik ANOVA, nilai persentase pengurangan panjang luka stadium II dengan perlakuan sediaan gel transglutaminase 5\% lebih tinggi dan berbeda nyata dibandingkan perlakuan dengan Bioplacenton ${ }^{\circledR}$ gel (kontrol positif). Oleh karena itu, sediaan gel enzim transglutaminase 5\% dapat berperan sebagai penyembuh luka stadium II pada ayam ras jantan.

Konsentrasi enzim yang rendah dapat menyebabkan lambatnya aktivitas penyembuhan luka. Sediaan gel enzim transglutaminase $7 \%$ memiliki aktivitas pengurangan panjang luka yang tidak maksimal karena $\mathrm{pH}$ sediaan gel transglutaminase tidak berada pada $\mathrm{pH}$ optimum enzim sehingga aktivitas penyembuhan luka pun terhambat. Persentase pengurangan panjang luka pada kontol positif sebesar 99,33\%. Nilai tersebut mendekati dengan nilai persentase pengurangan panjang luka pada sediaan gel enzim transglutaminase 5\%. Pisano et al., [6] menyatakan bahwa enzim transglutaminase dapat membantu stabilisasi monomer fibrin yang terjadi selama proses pembekuan darah. Enzim ini terlibat pada berbagai fungsi biologis mulai dari penggumpalan darah sampai diferensiasi sel [7]. Oleh sebab itu, enzim transglutaminase dalam sediaan gel terbukti berperan dalam proses penyembuhan luka.

Enzim transglutaminase mempunyai $\mathrm{pH}$ optimum pada $\mathrm{pH}$ 6,5 [5] sehingga pada $\mathrm{pH}$ tersebut aktivitas enzim akan mencapai titik optimum. Pada berbagai sediaan gel enzim transglutaminase, hanya sediaan gel enzim transglutaminase 5\% yang memiliki $\mathrm{pH}$ 6,5 yang setara dengan $\mathrm{pH}$ optimum enzim. Oleh karena itu, sediaan gel enzim transglutaminase 5\% mempunyai aktivitas penyembuhan luka paling cepat. Nilai $\mathrm{pH}$ sediaan gel enzim transglutaminase $1 \%, 3 \%$ dan $7 \%$ memiliki nilai pH masing-masing 6,2; 6,3; dan 6,7. Kisaran $\mathrm{pH}$ tersebut dapat menyebabkan aktivitas enzim transglutaminase memiliki aktivitas yang menurun akibat tidak sesuainya $\mathrm{pH}$ dengan $\mathrm{pH}$ optimum enzim transglutaminase. Oleh sebab itu, pada sediaan gel enzim transglutaminase $1 \%, \quad 3 \%$ dan $7 \%$ memiliki aktivitas penyembuhan luka lebih lambat dan memiliki aktivitas penyembuhan optimum pada gel enzim transglutaminase 5\%.

Tabel 3. Persentase Pengurangan Panjang Luka

\begin{tabular}{|c|c|c|c|}
\hline \multirow[b]{2}{*}{ Perlakuan } & \multicolumn{2}{|c|}{$\begin{array}{c}\text { Panjang luka } \\
(\mathrm{cm})\end{array}$} & \multirow{2}{*}{$\begin{array}{c}\text { Persentase } \\
\text { penguranga } \\
n \\
\text { panjang luka } \\
(\%)\end{array}$} \\
\hline & $\begin{array}{l}\text { Hari } \\
\text { ke-0 }\end{array}$ & $\begin{array}{l}\text { Hari } \\
\text { ke-10 }\end{array}$ & \\
\hline Kelompok A & 2,95 & 0,90 & $71,48^{\mathrm{a}}$ \\
\hline Kelompok B & 2,98 & 0,02 & $99,33^{\mathrm{b}}$ \\
\hline Kelompok C & 2,98 & 0,58 & $80,54^{\mathrm{c}}$ \\
\hline Kelompok D & 2,99 & 0,03 & $99,00^{\mathrm{d}}$ \\
\hline Kelompok E & 2,99 & 0,01 & $99,67^{\mathrm{e}}$ \\
\hline Kelompok F & 2,98 & 0,38 & $87,25^{\mathrm{c}}$ \\
\hline
\end{tabular}

Keterangan: Angka yang diikuti oleh huruf yang sama menunjukkan tidak berbeda nyata pada taraf uji Duncan 5\%

Kelompok A : luka diberi dasar gel (kontrol negatif).

Kelompok B : luka diberi Bioplacenton ${ }^{\circledR}$ gel (kontrol positif).

Kelompok $\mathrm{C}$ : luka diberi formula 1 (konsentrasi $\quad 1 \% \quad$ enzim transglutaminase).

Kelompok D : luka diberi formula 2 (konsentrasi $\quad 3 \% \quad$ enzim transglutaminase).

Kelompok E : luka diberi formula 3 (konsentrasi $5 \%$ enzim transglutaminase). 


\author{
Kelompok F : luka diberi formula \\ 4 (konsentrasi $7 \%$ enzim \\ transglutaminase).
}

\section{SIMPULAN}

Formulasi sediaan gel enzim transglutaminase memiliki tekstur yang homogen, berwarna putih, berbau khas enzim transglutaminase, dan memiliki kisaran $\mathrm{pH}$ 6,2 6,7. Persentase pengurangan panjang luka stadium II pada ayam ras jantan oleh sedian gel enzim transglutaminase $1 \%, 3 \%$, 5\% dan $7 \%$ masing-masing sebesar 80,54\%, 99,00\%, $99,67 \%$ dan $87,25 \%$. Persentase pengurangan panjang luka stadium II pada ayam ras jantan oleh Bioplacenton ${ }^{\circledR}$ sebesar 99,33\%. Berdasarkan analisis statistik ANOVA, nilai persentase pengurangan panjang luka stadium II dengan perlakuan sediaan gel transglutaminase $5 \%$ lebih tinggi dan berbeda nyata dibandingkan perlakuan dengan Bioplacenton ${ }^{\circledR}$ gel (kontrol positif). Oleh karena itu, sediaan gel enzim transglutaminase 5\% dapat berperan sebagai penyembuh luka stadium II pada ayam ras jantan.

\section{SARAN}

Perlu dilakukan uji mutu dan uji stabilitas terhadap gel enzim transglutaminase baik secara fisik, kimia dan mikrobiologi. Selain itu, juga perlu dilakukan penelitian lebih lanjut untuk mengetahui aktivitas enzim transglutaminase dalam sediaan gel dan mempelajari mekanisme yang menyebabkan enzim transglutaminase dapat mempercepat proses penyembuhan luka secara klinis.

\section{DAFTAR PUSTAKA}

[1]. Nonaka, M., Tanaka, H., Okiyama, A., Motoki, M., Ando, H., Umeda, K., Matsuura, A. 1989. Polymerization of several protein by $\mathrm{Ca}^{2+}$ independent transglutaminase derived from microorganisms. Agric. Biol. Chem53: 2619-2623.

[2]. Grades, Z.E.A. 2006. Stability of microbial transglutaminase and its reactions with individual caseins under atmospheric and high pressure. Disertasi. Mexiko City: Fakultät Mathematik und
Naturwissenschaften. Universität Dresden.

[3]. Cortez, J., Bonner, P.L.R., Griffin, M. 2004. Application of transglutaminases in the modification of wool textiles. Enz. Microb. Technol. 34: 64.72.

[4]. Cortez, J., Bonner, P.L.R., Griffin, M. 2005. Transglutaminase treatment of wool fabrics leads to resistance to detergent damage. J Biotechnol. 116: 379386.

[5]. Ando, H., Adachi, M, Umeda, K., Matsuura, A., Nonaka, M., Uchio, R., Tanaka, H., Motoki, M. 1989. Purification and characterization of novel transglutaminase derived from microorganism. Agric. Biol. Chem53:2613-2617.

[6]. Pisano, J. J., Finlayson, J. S. and Peyton, M. P. 1968. Cross-link in @brin polymerized by factor 13: e-(c-glutamyl)lysine.Science. 160, 892-893.

[7]. Srianta. 2000. Potensi Aplikasi Transglutaminase dalam Industri Pangan. FTP UKWM. Surabaya.

[8]. Allen, L. V. 2002. The Art Science and Technology of Pharmaceutical Compounding, 308-310, American Pharmaceutical Association. Washington DC.

[9]. Aiache. 1993. Biofarmasetika, diterjemahkan oleh Widji Soerartri Edisi II, Airlangga Press. Jakarta.

[10].Sjamsuhidajat, R, de Jong, W. 2010. Buku Ajar Ilmu Bedah, Edisi 3, EGC. Jakarta. 